\title{
GEOLOGICAL SURVEY OF CANADA RADIOCARBON DATES III
}

\author{
W. DYCK and J. G. FYLES* \\ Geological Survey of Canada, Ottawa, Canada \\ INTRODUCTION
}

All $\mathrm{C}^{14}$ measurements in this date list were made with the $2 \mathrm{~L}$ counter described in our first date list (GSC I). Ages were calculated on a $\mathrm{C}^{14}$ half life of $5570 \pm 30 \mathrm{yr}$ and 0.95 of the activity of the NBS oxalic-acid standard, and are quoted in years before 1950.

In addition to the counting errors of sample, background, and standard, and the errors in the half life, all age errors starting with sample GSC-120 include an error term to account for the average variation of $\pm 1.5 \%$ in the $\mathrm{C}^{14}$ concentration during the past $1300 \mathrm{yr}$ as measured by Willis, Tauber, and Münnich (1960) in sequoia tree rings. Similar results have been obtained by the author in work on an 1100-yr old Douglas fir from Vancouver Island, now nearing completion. The error term inserted to cover this variation makes little difference to the resultant error of older samples but gives a more realistic error for the young samples. For instance, in samples up to $1000 \mathrm{yr}$ old, this correction generally accounts for about $50 \%$ of the age error, in a $10,000 \mathrm{yr}$ sample about $30 \%$, and in a 20,000 yr sample about $5 \%$.

No changes were made in the routine chemical pretreatment and $\mathrm{CO}_{2}$ preparation of organic samples. Sea shells with GSC numbers greater than 149 were treated with $\mathrm{HCl}$ to remove the outer $20 \%$ before the $\mathrm{CO}_{2}$ was collected for dating, rather than the outer $10 \%$ as in our earlier procedure. Occasionally, more or less of a shell sample was removed depending on the size and condition of the sample. Deviations from the routine procedure are listed under the respective samples. This change in the shell pretreatment was prompted by the results of four samples that were analyzed in two fractions after the usual $10 \%$ preleach, and of one sample that was prepared twice. The two fractions and the corresponding dates of these samples are listed in the following table.

\begin{tabular}{|c|c|c|}
\hline Date No. & Fraction, $\%$ & Age, years \\
\hline \multirow[t]{2}{*}{ GSC-61 } & $10-50$ & $10,360 \pm 240$ \\
\hline & $51-100$ & $10,540 \pm 210$ \\
\hline \multirow[t]{2}{*}{ GSC-111 } & $11-50$ & $30,300 \pm 1600$ \\
\hline & $51-100$ & $36,300 \pm 2000$ \\
\hline \multirow[t]{2}{*}{ GSC-119 } & $11-70$ & $10,460 \pm 160$ \\
\hline & $71-100$ & $10,740 \pm 170$ \\
\hline \multirow[t]{2}{*}{ GSC-146 } & $13-55$ & $7620 \pm 210$ \\
\hline & $56-100$ & $8200 \pm 220$ \\
\hline \multirow{2}{*}{$\begin{aligned} \text { GSC-134 } & \text { (1st preparation) } \\
& (2 \text { nd preparation) }\end{aligned}$} & $11-100$ & $29,430 \pm 680$ \\
\hline & $63-100$ & $29,800 \pm 220$ \\
\hline
\end{tabular}

* The introductory part of this paper has been prepared by the first author who operates the laboratory. The date list has been compiled by the second author from descriptions of samples and interpretations of dates by the various collectors. 
The innermost fraction is consistently older in all five samples suggesting slight contamination, although the differences between the two fractions are smaller than the sum of the absolute errors of the two fractions in all but two samples. While the errors are within statistical limits the differences between the two fractions are not those predicted by chance. If chance alone were operative there should be just as many samples in which the inner fraction is younger.

No measurements like those listed in the table above have been made with samples from which the outer $20 \%$ were removed, but it is expected that this procedure will remove most of the remaining contamination. It is not impossible, however, that in very old shells the contaminating $\mathrm{C}$ has penetrated the whole thickness of the shell.

\section{SAMPLE DESCRIPTIONS}

I. GEOLOGIC SAMPLES

\section{A. Eastern Canada}

\section{GSC-160. Tignish Shore, Prince Edward Island $\quad 12,670 \pm 340$}

Marine shell fragments (Macoma, Astarte, Balanus) coll. 6 to $20 \mathrm{ft}$ below summit of gravel knoll (alt ca. $25 \mathrm{ft}$ ) beside road to North Point, ca. $1 \mathrm{mi} \mathrm{N}$ of Tignish Shore, Prince Edward Island ( $46^{\circ} 58^{\prime} 30^{\prime \prime} \mathrm{N}$ Lat, $63^{\circ} 59^{\prime} 45^{\prime \prime} \mathrm{W}$ Long). Half shells of Astarte from depth $20 \mathrm{ft}$. Deposit probably is glaciomarine. Coll. 1962 by V. K. Prest.* Comment (V.K.P.) : the shell-bearing material presumably originated during glacial retreat from NW Prince Edward Island, when the seashore was $80 \mathrm{ft}$ above present sealevel (Prest, 1962). Date agrees with GSC-101: 12,410 \pm 170 (GSC-II) for shells $10 \mathrm{mi}$ SW ascribed to a shore at alt $50 \mathrm{ft}$. Outer $10 \%$ of shells discarded. Sample mixed with dead gas for counting. Date based on one 3-day count.

\section{GSC-119. Glennevis, Ontario \\ $10,740 \pm 170$ 8790 в.C.}

Marine shells (Macoma balthica) from road cut $1 \mathrm{mi} \mathrm{N}$ of Glennevis, Ontario ( $45^{\circ} 17.6^{\prime} \mathrm{N}$ Lat, $74^{\circ} 29.8^{\prime} \mathrm{W}$ Long), from sand overlapping marine clay on edge of till hill. Sand appears to be a shore or near-shore deposit; thus shells are inferred to relate to a stand of the Champlain Sea at or slightly above the site (alt $258 \mathrm{ft}$ ). Coll. 1961 by J. J. L. Tremblay. Comment: although slightly older than expected, date agrees approx. with other dates for shells from Ottawa-Montreal region. Outer and inner fractions of sample were dated separately, after removal of outermost $10 \%$ of shells: outer fraction ( $11-70 \%$ leach) $10,460 \pm 160$ inner fraction (71-100\% leach) $10,740 \pm 170$

Each date is based on a single count. The inner fraction was mixed with dead gas for counting.

\section{GSC-131. Big Swamp, Picton, Ontario}

Peat coll. with Hiller peat sampler from base of bog overlying lacustrine * All persons referred to as collectors or submitters of samples or cited as sources of data are with the Geological Survey of Canada unless otherwise specified. 
sediments at alt ca. $300 \mathrm{ft}$ in a depression in limestone bedrock, $4.5 \mathrm{mi} \mathrm{NW}$ of Picton, Ontario (44. $02^{\prime} \mathrm{N}$ Lat, $77^{\circ} 14^{\prime} \mathrm{W}$ Long). Depth below surface, 265 to $275 \mathrm{~cm}$. Coll. 1962 by J. Terasmae. Comment (J.T.) : pollen sequence from this locality correlates with that from nearby Rossmore bog at alt $245 \mathrm{ft}$, and extends below dated level approx. to level of GSC-157 (9480 \pm 170 , this list) in Rossmore bog. Sample pretreatment did not include usual $\mathrm{NaOH}$-leach.

\section{GSC-156. Roblin Lake, Ontario}

Gyttja from Roblin Lake ca. $7 \mathrm{mi}$ S of Belleville, Ontario $\left(44^{\circ} 03^{\prime} \mathrm{N}\right.$ Lat, $77^{\circ} 25^{\prime} \mathrm{W}$ Long) ; coll. in 2 -in. Shelby tube from base of dark brown finedetritus gyttja $45 \mathrm{ft}$ below lake bed and $76 \mathrm{ft}$ below water level (alt $361 \mathrm{ft}$ ). Sampled layer is underlain in sequence by inorganic sediments, glacial deposits, and limestone. Coll. 1963 by J. Terasmae and E. Mirynech. Comment (J.T.) : date marks beginning of rapid deposition of organic sediment, probably resulting from climatic change at beginning of Hypsithermal time. Palynological record in the core extends deeper than dated level. Correlation of this pollen record with those from Rossmore bog (GSC-157, this list) and Victoria Road bog (GSC-132, this list) indicates that recession of the lake in Ontario basin (transition Lake Iroquois to Lake Ontario) below level of Roblin Lake took place considerably earlier than this date, probably prior to $9500 \mathrm{yr}$ ago. Date based on one 3-day count. $\mathrm{NaOH}$-leach omitted from pretreatment of sample.

\section{GSC-157. Rossmore Bog, Ontario}

$9480 \pm 170$

7530 в.c.

Gyttja coll. with piston sampler at 320 to $330 \mathrm{~cm}$ depth in bog ca. $3 \mathrm{mi} \mathrm{S}$ of Belleville, Ontario ( $44^{\circ} 07^{\prime} \mathrm{N}$ Lat, $77^{\circ} 23^{\prime} \mathrm{W}$ Long). Sample from base of gyttja overlying inorganic lacustrine and glacial deposits. Surface of bog is at alt of Lake Ontario (ca. $245 \mathrm{ft}$ ). Coll. 1962 by J. Terasmae. Comment (J.T.) : date is minimum for establishment of Lake Ontario at or near its present level, following abandonment of the Iroquois level and short-lived intermediate levels. $\mathrm{NaOH}$-leach was omitted from pretreatment of sample.

\section{GSC-132. Victoria Road Bog, Kirkfield, Ontario $\quad 9600 \pm 190$}

Gyttja $565 \mathrm{~cm}$ below bog surface at alt ca. $825 \mathrm{ft}, 3.6 \mathrm{mi}$ NE of Kirkfield, Ontario (44. $37^{\prime} \mathrm{N}$ Lat, $78^{\circ} 57^{\prime} \mathrm{W}$ Long). Coll. with piston sampler from lowest organic layer in bog and lake deposits overlying alluvial sand in an abandoned channel. Coll. 1962 by J. Terasmae. Comment (J.T.) : date gives minimum age for abandonment of the Kirkfield outlet between the Huron and Ontario Lake basins. Date based on one 3-day count. Sample pretreatment did not include usual $\mathrm{NaOH}$-leach.

\section{GSC-130. Copetown bog, Ontario \\ $9230 \pm 180$ 7280 в.C.}

Peat and gyttja coll. with Hiller peat sampler at 720 to $730 \mathrm{~cm}$ depth, ca.

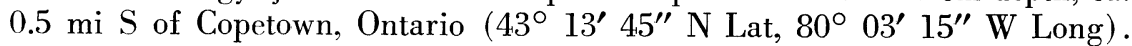
Sample from base of organic deposit overlying inorganic lacustrine sediment at alt ca. $800 \mathrm{ft}$ in a depression in drift. Coll. 1961 by J. M. Stewart, McMaster Univ.; subm. by J. Terasmae. Comment (J.T.) : pollen record from this bog extends below GSC-130 and has been correlated with sequences from Galt and 
Hamilton with basal $\mathrm{C}^{14}$ dates of 11,950 \pm 350 (I(GSC)-29) and 10,150 \pm 450 (I(GSC) -11), respectively (see Isotopes $\mathrm{I}), \mathrm{C}^{14}$ dates from the three sites support the pollen correlation. $\mathrm{NaOH}-l$ each was omitted from pretreatment of sample.

\section{GSC-92. Churchill, Manitoba}

Marine pelecypod shells (Hiatella arctica and Mya truncata) from surface of emerged beach, alt ca. $465 \mathrm{ft}$, probably a few $\mathrm{ft}$ to tens of $\mathrm{ft}$ below marine limit, $55 \mathrm{mi} \mathrm{SW}$ of Churchill, Manitoba $\left(58^{\circ} 11^{\prime} \mathrm{N} \mathrm{Lat}, 95^{\circ} 03^{\prime} \mathrm{W}\right.$ Long). Coll. 1960 by J. D. Aitken for B. G. Craig. Comment (B.G.C.) : sample gives minimum date for retreat of Laurentide ice from area and for entry of Tyrrell Sea (Lee, 1960) into SW Hudson Bay.

\section{B. Western Canada}

\section{GSC-141. Waldron Ranch, Alberta}

Small pieces of charcoal scattered through silty clayey alluvium of Oldman River in gully at Waldron Ranch, ca. $16 \mathrm{mi} \mathrm{N}$ of Lundbreck, Alberta (SEl/4, Sec. 7 , tp. 10 , rge. 1 , W 5th Mer.: $49^{\circ} 48^{\prime} \mathrm{N}$ Lat, $114^{\circ} 07^{\prime} \mathrm{W}$ Long). Alluvium overlies varved silt and clay which overlies Laurentide till. Sample from 2 to $12 \mathrm{ft}$ below ground level and below a 1/2-in. bed of volcanic ash probably equivalent to ash overlying GSC-161. Coll. 1960 by A. M. Stalker. Comment: sample pretreatment did not include usual $\mathrm{NaOH}$-leach. Date based on a single long count. Sample mixed with dead gas for counting.

\section{GSC-161. Blood Indian Reserve, Alberta $\quad 10,620 \pm 250$ \\ 8670 в.C.}

Organic matter from $\mathrm{N}$ bank St. Mary River in Blood Indian Reserve ca. $10 \mathrm{mi}$ S of Lethbridge, Alberta (NW1/4, Sec. 4, tp. 7, rge. 22, W 4th Mer.: $49^{\circ} 32^{\prime} 30^{\prime \prime} \mathrm{N}$ Lat, $112^{\circ} 56^{\prime} 30^{\prime \prime} \mathrm{W}$ Long), 2.5 to $3.5 \mathrm{ft}$ below top of 4 -ft soil profile forming base of $14 \mathrm{ft}$ of alluvial and eolian deposits overlying varved clay and silt, in turn overlying youngest Laurentide till in vicinity. A 1-in. bed of volcanic ash above sampled soil probably is equivalent to ash layer overlying GSC-141. Coll. 1962 by A. M. Stalker. Comment: date based on single count. $\mathrm{NaOH}$-leach omitted from sample pretreatment.

\section{GSC-169. Downie Creek, British Columbia $\quad 3760 \pm 140$}

Spruce wood (id. by R. J. Mott) from alt $6900 \mathrm{ft}$ at head of Downie Creek ca. $25 \mathrm{mi} \mathrm{N}$ of Revelstoke, British Columbia $\left(51^{\circ} 18^{\prime} \mathrm{N} \mathrm{Lat}, 118^{\circ} 01^{\prime}\right.$ W Long). Sample from one of three logs $1 \mathrm{ft}$ in diam and up to $6 \mathrm{ft}$ long partly embedded in outwash $1000 \mathrm{ft}$ beyond glacier snout and $900 \mathrm{ft}$ above tree line. Coll. 1962 by J. O. Wheeler. Comment: the wood is probably from a tree that grew within the area covered by the glacier at its 19th-century maximum and at least $900 \mathrm{ft}$ above the present tree line when the climate was more favorable than today.

\section{GSC-168. Fort Langley, British Columbia}

$11,930 \pm 190$

Shells (Macoma calcarea) from marine clay $25 \mathrm{ft}$ below land surface and 
$40 \mathrm{ft}$ above sealevel, in excavation for Trans-Canada Highway SE of Fort Langley, Langley Municipality, British Columbia $\left(49^{\circ} 10^{\prime} \mathrm{N}\right.$ Lat, $122^{\circ} 35^{\prime} \mathrm{W}$ Long). Coll. 1963 by J. E. Armstrong. Comment (J.E.A.) : shells accumulated during post-Vashon marine submergence, and prior to or contemporaneous with Sumas ice advance a few mi E.

\section{GSC-124. Coquitlam, British Columbia}

$$
\begin{aligned}
& \mathbf{2 6 , 4 5 0} \pm \mathbf{5 2 0} \\
& \mathbf{2 4 , 5 0 0} \text { в.c. }
\end{aligned}
$$

Peaty silt from Maryhill gravel pit, Coquitlam Municipality, Lower Fraser Valley, British Columbia ( $49^{\circ} 14^{\prime} \mathrm{N}$ Lat, $122^{\circ} 47^{\prime} \mathrm{W}$ Long), from silty bed near base of ca. $50-\mathrm{ft}$ section of nonglacial sandy alluvium overlain by $100 \mathrm{ft}$ $(+)$ of Vashon drift and underlain by till and clay. Coll. 1962 by J. E. Armstrong. Comment (J.E.A.) : this is first dated occurrence of Quadra sediments in Fraser Lowland E of Vancouver metropolitan area. Date based on one 3-day count.

\section{Icarus Point series, Vancouver Island, British Columbia}

Peat from two levels on wooded sea cliff at Icarus Point, NW of Nanaimo, Vancouver Island, British Columbia $\left(49^{\circ} 14.5^{\prime} \mathrm{N}\right.$ Lat, $124^{\circ} 00.5^{\prime} \mathrm{W}$ Long). Exposed section includes 3 tills separated by 2 series of stratified sediments containing peat.

\section{GSC-98. Icarus Point, upper peat}

Peat about $60 \mathrm{ft}$ above beach, from 5 -ft section of silt and fine sand with wood fragments and peat partings overlain and underlain by till. The sampled strata comprise the basal part of the upper series of intertill sediments. Coll. 1958 by J. G. Fyles. NaOH-leach omitted from sample pretreatment.

\section{GSC-155. Icarus Point, lower peat}

Peat about $28 \mathrm{ft}$ above beach, from prominent 6 to $10 \mathrm{in}$. peat bed within $10 \mathrm{ft}$ of silt underlain by $15 \mathrm{ft}$ of sand and $10 \mathrm{ft}$ of marine clay. These strata comprise the lower series of intertill sediments and lie beneath the till sheet beneath GSC-98. Coll. 1962 by E. C. Halstead.

General Comment: the upper intertill series was assumed equivalent to Quadra sediments (typical dates 25,000 to $30,000 \mathrm{yr}$ ). The infinite date of GSC-98 raises the possibility that unit is older than the Quadra (see GSC-81, 94, 99, GSC-II).

\section{Crofton series, Vancouver, British Columbia}

Peat and wood from interglacial or interstadial strata exposed in excavations at British Columbia Forest Products' pulp mill .75 mi N of Crofton, Vancouver Island, British Columbia (48 $52^{\prime} 30^{\prime \prime} \mathrm{N}$ Lat, $123^{\circ} 38^{\prime} 40^{\prime \prime} \mathrm{W}$ Long). Coll. by E. C. Halstead.

GSC-163. Crofton peat

Peat from 4 to 6 in. bed of peaty silt and wood at alt $100 \mathrm{ft}$ on $40 \mathrm{ft}$ face 'behind' the pulp mill. Peat bed lies within $15 \mathrm{ft}$ of silt and clay underlain by sand and overlain by $10 \mathrm{ft}$ of silty sand; this succession is overlain and truncated by the surface (Vashon) till. Coll. 1963. Comment (E.C.H.) : peat-bear- 
ing beds are similar to the Quadra sediments but the infinite date suggests they are older. Date based on a single count.

GSC-153. Crofton wood

Wood fragments from fresh exposure on partly overgrown sea cliff adjacent to railway below pulp mill, associated with layers of sparse fine plant material within silt and fine sand at alt $15 \mathrm{ft}$. These materials appear to constitute a channel fill truncating laminated silt and clay and younger than the strata enclosing GSC-163. Coll. 1962.

\section{Northern Canada, General}

\section{GSC-88. Hunker Creek ( silt), Yukon}

$$
\begin{gathered}
30,800 \pm 1600 \\
-1400 \\
28,850 \text { в.C. }
\end{gathered}
$$

Fine plant detritus from frozen silt beneath a 20 -ft bed of woody, silty peat in right bank of Hunker Creek at mouth of Last Chance Creek, Klondike Dist., Yukon $\left(64^{\circ} 01^{\prime} \mathrm{N}\right.$ Lat, $139^{\circ} 06^{\prime} \mathrm{W}$ Long $), 2 \mathrm{ft}$ above creek level and $4 \mathrm{ft}$ below top of silt. Coll. 1961 by J. Terasmae and O. L. Hughes. Comment: wood from base of peat at depth $20 \mathrm{ft}$ dates $9520 \pm 130$ (GSC-73: GSC II). Dates confirm existence of a major stratigraphic break between silt and overlying peat. Silt is tentatively correlated (O.L.H.) with similar material, $4.5 \mathrm{mi}$ upstream along Hunker Creek, beneath a bone-bearing gravel that yielded wood dated >35,000 (I(GSC)-181, Isotopes II). NaOH-leach was omitted from sample pretreatment. Date based on single 4-day count.

\section{GSC-121. Porcupine River, Yukon $\quad 10,740 \pm 180$ \\ 8790 в.C.}

Peat $4 \mathrm{ft}$ below ground on upper part of $\mathrm{S}$ bank of Porcupine River, Yukon ( $67^{\circ} 28^{\prime} \mathrm{N}$ Lat, $139^{\circ} 54^{\prime}$ W Long), from base of marly peat with freshwater shells overlying silty clay which overlies a thick section of silt with minor sand and gravel. Coll. 1962 by O. L. Hughes. Comment (O.L.H.) : silty clay beneath peat possibly accumulated in a lake when meltwater from Laurentide Ice Sheet discharged into Porcupine Basin through McDougall Pass and/or through headwaters of Eagle River, perhaps as recently as late Wisconsin. $\mathrm{NaOH}$-leach omitted from sample pretreatment.

\section{GSC-128. 'Gill' Lake, Yukon \\ $12,550 \pm 190$ \\ 10,600 в.c.}

Silty gyttja from NW side of 'Gill' Lake, Yukon $\left(65^{\circ} 28^{\prime}\right.$ N Lat, $139^{\circ} 42^{\prime}$ W Long), coll. with SIPRE coring drill at depth 91 to 93 in. near base of permanently frozen bog in a depression in terminal moraine of a former valley glacier. Coll. 1962 by O. L. Hughes. Comment (O.L.H.) : date is compatible with view that the moraine relates to a glacial advance distinctly older than the latest advance in the Ogilvie Mtn area (Vernon and Hughes, in press). Minimum date for the latter is GSC-50: $7510 \pm 100$ (GSC-I) for basal peat on a moraine at North Fork Pass, Yukon. Sample pretreatment did not include usual NaOH-leach.

\section{King Point series, Yukon}

Peat and wood from deposits exposed on rapidly eroding sea cliff $\mathrm{E}$ of 
King Point, Arctic coast, Yukon $\left(69^{\circ} 04.5^{\prime} \mathrm{N}\right.$ Lat, $137^{\circ} 50^{\prime} \mathrm{W}$ Long). Coll. 1962 by O. L. Hughes.

GSC-151. King Point, beneath till

Wood and peaty fragments coll. $2 \mathrm{ft}$ above base of sea cliff $3.5 \mathrm{mi} \mathrm{E}$ of $\mathrm{E}$ end of King Point spit. Sample from organic silt grading up into stony clay with marine shells (thickness 10 to $18 \mathrm{ft}$ ) overlain in succession by till (20 to $30 \mathrm{ft}$ ), sand and silt ( 8 to $15 \mathrm{ft}$ ), and surface peat (up to $3 \mathrm{ft}$ ). The till, representing last glaciation of site, apparently terminates in vicinity of a moraine, ca. $4 \mathrm{mi} \mathrm{W}$, which is assumed to mark maximum (classical?) Wisconsin stand of Laurentide Ice Sheet.

\section{GSC-159. King Point, above till}

$9510 \pm 170$

7560 в.с.

Peat $18 \mathrm{ft}$ below ground level $0.2 \mathrm{mi} \mathrm{W}$ of GSC-151, from 2-in. peat bed in silt $4 \mathrm{ft}$ above till in stratigraphic section similar to that at GSC-151. Sample treated with cold (rather than hot) $\mathrm{NaOH}$.

\section{GSC-120. Rat River, Northwest Territories}

Wood, in part beaver-chewed, from W side of Rat River, W of Mackenzie River, Northwest Territories ( $67^{\circ} 39.5^{\prime} \mathrm{N}$ Lat, $135^{\circ} 28^{\prime} \mathrm{W}$ Long); coll. near base of $40-\mathrm{ft}$ section of silt with organic layers, which overlies till over gravel. No till was seen above silt in poorly exposed upper part of section, but evidence from surrounding area suggests that Laurentide ice covered the site and extended several mi W in (classical?) Wisconsin time. Coll. 1962 by O. L. Hughes.

\section{GSC-147. Rat River, Northwest Territories}

Wood (twigs) $12 \mathrm{ft}$ below ground on back wall of flow slide on $\mathrm{N}$ bank of Rat River, W of Mackenzie River, Northwest Terirtories $\left(67^{\circ} 43.5^{\prime} \mathrm{N}\right.$ Lat, $135^{\circ} 50.5^{\prime} \mathrm{W}$ Long). Sample from organic silt $0.4 \mathrm{ft}$ thick beneath clay, silt, and peat, and resting on $1 \mathrm{ft}$ of clay over sand. The dated layer may have originated in pond or floodplain antedating modern valley of Rat River. Coll. 1962 by O. L. Hughes. Sample mixed with dead gas for counting.

\section{MacAlpine Lake series}

Pelecypod shells and peat collected in two localities a few mi apart to determine approximate date of ice recession and age of highest marine beaches. Coll. 1962 by W. Blake, Jr.

\section{GSC-110. MacAlpine Lake, shells}

Whole shells and fragments of Hiatella arctica from surface and down to $1 \mathrm{ft}$ depth in silt, alt ca. $600 \mathrm{ft}, 18 \mathrm{mi} \mathrm{NW}$ of MacAlpine Lake, Northwest Territories $\left(66^{\circ} 49^{\prime} \mathrm{N}\right.$ Lat, $103^{\circ} 28^{\prime} \mathrm{W}$ Long). Date based on one 3-day count.

GSC-116. MacAlpine Lake, peat

$$
\begin{array}{r}
1090 \\
\text { A.D. } 860
\end{array}
$$

Basal peat 10 to 12 in. below surface of tussock, and underlain by sand and gravel, between beaches on an esker, alt ca. $630 \mathrm{ft}, 5 \mathrm{mi} \mathrm{N}$ of MacAlpine Lake, Northwest Territories ( $66^{\circ} 47^{\prime}$ N Lat, $103^{\circ} 04^{\prime}$ W Long). Chemical pre- 
treatment omitted from sample preparation. Sample mixed with dead gas for counting.

General Comment (W.B., Jr.) : because the shells are within $50 \mathrm{ft}$ of highest marine beaches (ca. $650 \mathrm{ft}$ alt) pelecypods are believed to have lived when the highest beaches were being formed immediately after the glacial retreat. Blake (1963) cites evidence that edge of ice-sheet was still at end moraine along $\mathrm{N}$ edge of MacAlpine Lake $8160 \mathrm{yr}$ ago. Peat was dated in unsuccessful attempt to obtain independent check on age of highest beaches.

\section{GSC-115. Bathurst Inlet \\ $8370 \pm 100$ \\ 6420 в.c.}

Whole shells of Hiatella arctica, and fragments of Hiatella, Mya sp., and Macoma balthica from surface and down to $1 \mathrm{ft}$ depth in silt between ca. 650 and $670 \mathrm{ft}$ alt, $4 \mathrm{mi} \mathrm{W}$ of Bathurst Inlet, Northwest Territories $\left(66^{\circ} 32^{\prime} \mathrm{N}\right.$ Lat, $107^{\circ} 42^{\prime}$ W Long). Coll. 1962 by W. Blake, Jr. Comment (W.B., Jr.) : shells are the highest found in region, and presumably date highest beaches, at 700 to $750 \mathrm{ft}$.

\section{GSC-125. Mt. George, Kent Peninsula $\quad 9190 \pm 210$ \\ 7240 в.с.}

Shells of Mya truncata on surface of beaches on top of Mt. George, the highest point (alt ca. $610 \mathrm{ft})$ on Kent Peninsula, Northwest Territories $\left(68^{\circ}\right.$ 39.5' N Lat, $107^{\circ} 01^{\prime}$ W Long). Coll. 1962 by H. H. Bostock for W. Blake, Jr. Comment (W.B., Jr.) : the dated pelecypods indicate that Kent Peninsula was ice free $9200 \mathrm{yr}$ ago. Higher beaches do not exist on Kent Peninsula, but the marine limit elsewhere along the mainland coast is close to $700 \mathrm{ft}$. Shells probably date highest beaches. Sample mixed with dead gas for counting.

\section{Gordon Bay series}

Plant debris and pelecypod shells coll. in deltaic beds of silt and sand in attempt to determine recent rate of land uplift. The nearly flat-lying deltaic beds are exposed at the head of Gordon Bay on E side of Bathurst Inlet, Northwest Territories ( $66^{\circ} 49.5^{\prime} \mathrm{N}$ Lat, $107^{\circ} 05^{\prime} \mathrm{W}$ Long). Top surface of delta below surface peat is at alt of $29 \mathrm{ft}$. Coll. 1962 by W. Blake, Jr.

\section{GSC-138. Gordon Bay, plant debris}

$2170 \pm 140$

Leaves and twigs of birch, alder, and willow, and fragmen 220 B.c. from $19 \mathrm{ft}$ alt. Date based on one 3-day count.

\section{GSC-137. Gordon Bay, shells}

$$
\begin{array}{r}
1850 \\
\text { A.D. } 100
\end{array}
$$

Whole shells and fragments of Mytilus edulis at $24 \mathrm{ft}$ alt. Date based on cne 3-day count.

General Comment (W.B., Jr.) : the changing fauna and increasing coarseness of sediments upward in section indicate imminent approach of shoreline, and eveness of surface of delta suggests that little erosion has occurred since emergence. Thus Mytilus and accompanying fragile Macoma balthica in living position are believed to have lived when beds now at $29 \mathrm{ft}$ alt were at or close to sealevel. If so, uppermost sediments were being deposited ca. $2000 \mathrm{yr}$ ago, 
and, if constant sealevel is assumed, uplift since then has averaged $1.5 \mathrm{ft}$ per century (Blake, 1963).

\section{Melville Sound series}

Plant debris, pelecypod shells, and peat coll. in and on top of silty and sandy, gently dipping deltaic beds in unnamed bay on S side of Melville Sound, Northwest Territories ( $68^{\circ} 11.5^{\prime} \mathrm{N}$ Lat, $106^{\circ} 17^{\prime} \mathrm{W}$ Long). Uppermost sand beds in delta are at alt $29 \mathrm{ft}$. Coll. 1962 by W. Blake, Jr.

\section{GSC-152. Melville Sound, plant debris $\quad 3070 \pm 140$}

Twigs, leaves, and moss fragments from bed at ca. 24, ft alt deformed by growth of an ice wedge. Sample pretreatment included cold $\mathrm{NaOH}$-leach. Sample mixed with dead gas for counting.

GSC-158. Melville Sound, shells

$$
\begin{aligned}
& 2510 \pm 180 \\
& 560 \text { в.C. }
\end{aligned}
$$

Whole shells and fragments of the pelecypods Macoma balthica, Macoma calcarea, and Mya truncata at 26 to $28 \mathrm{ft}$ alt. Sample mixed with dead gas for counting.

\section{GSC-172. Melville Sound, peat}

$$
400 \pm 140
$$

Peat at $28 \mathrm{ft}$ on top of ice wedge and at base of peat layer 2 to $3 \mathrm{ft}$ thick that mantles surface of deltaic beds. Date based on single 3-day count.

General Comment (W.B., Jr.): dates on the organic debris and shells are similar to those obtained from Gordon Bay; possible reasons for the slight age differences appear elsewhere (Blake, 1963). Perhaps uplift during last $2500 \mathrm{yr}$ has been slightly slower at Melville Sound, about $100 \mathrm{mi} \mathrm{N}$ of Gordon Bay. Age of surface peat, which has accumulated since the delta emerged from the sea, gives no information as to time of passage of shoreline. Shell date indicates that the ice wedge started to develop within last $2500 \mathrm{yr}$, but because the surfice peat mantles the ice wedge as well as the deltaic beds, significant growth of the wedge ceased $400 \mathrm{yr}$ ago, or earlier.

\section{GSC-136. Lang River, Somerset Island}

$$
9180 \pm 170
$$$$
7230 \text { в.с. }
$$

Marine pelecypod shells (Hiatella arctica and Mya truncata) from surface of delta, alt $418 \mathrm{ft}, 3 \mathrm{mi}$ W of mouth of unnamed river $6 \mathrm{mi} \mathrm{S}$ of Lang River, E side Somerset Island, Northwest Territories $\left(72^{\circ} 11^{\prime} 30^{\prime \prime} \mathrm{N}\right.$ Lat, $94^{\circ} 05^{\prime} \mathrm{W}$ Long). Site probably ca. $100 \mathrm{ft}$ below marine limit. Coll. 1962 by B. G. Craig. Comment: date is minimum for retreat of Laurentide ice from area (see also Craig, in press, and L571 A, B, Lamont VII).

\section{GSC-150. Cunningham River, Somerset Island $\quad 9180 \pm 170$ 7230 в.с.}

Marine pelecypod shells (Hiatella arctica), $7 \mathrm{mi}$ inland from mouth of Cunningham River, Somerset Island, Northwest Territories $\left(73^{\circ} 59^{\prime} \mathrm{N}\right.$ Lat, $93^{\circ} 40^{\prime} \mathrm{W}$ Long), from eroded surface of marine silt at alt $204 \mathrm{ft}$, at least 200 ft below marine limit. Shells abundant; many occur paired in living position. Coll. 1962 by B. G. Craig. Comment: date is minimum for retreat of ice from $\mathrm{N}$ Somerset Island (Craig, in press). 


\section{Cape Alexander series, Boothia Peninsula}

Plant detritus and marine shells from bank of stream ca. 2 mi inland from small bay E of Cape Alexander, W side of Boothia Peninsula, Northwest Territories $\left(70^{\circ} 22^{\prime} \mathrm{N}\right.$ Lat, $96^{\circ} 19^{\prime} \mathrm{W}$ Long $)$. The bank, cut below a terrace at alt $72 \mathrm{ft}$, exposes alternating layers of plant detritus and sand containing marine pelecypod shells. Coll. 1962 by B. G. Craig.

\section{GSC-144. Cape Alexander, shells}

Shells of Astarte borealis coll. $4 \mathrm{ft}$ below ground level. Date based on one 3-day count.

\section{GSC-145. Cape Alexander, plant detritus}

Twigs, leaves, and other plant fragments from layer immediately above GSC-144. Sample pretreatment included cold $\mathrm{NaOH}$-leach. Sample mixed with dead gas for counting.

General Comment (B.G.C.): the two samples appeared to represent an estuarine-deltaic environment when seashore stood ca. $75 \mathrm{ft}$ above its present level. In view of other shell dates from the region (particularly Northern Keewatin series, GSC I) and disparity in age of the two samples, it is apparent that shells in this deposit have been redeposited from a higher site. Consequently, the strata may be alluvial rather than deltaic, and the 2120-yr plant material may have been deposited when shoreline was between sample site (alt $72 \mathrm{ft}$ ) and present shore.

\section{GSC-146. Makinson Inlet ( $\mathrm{S}$ arm), Ellesmere Island $\mathbf{8 2 0 0} \pm 220$}

Marine pelecypod shell fragments from surface of raised beach at head of S arm of Makinson Inlet, Ellesmere Island, Northwest Territories $\left(77^{\circ} 10^{\prime}\right.$ $\mathrm{N}$ Lat, $81^{\circ} 50^{\prime} \mathrm{W}$ Long), at ca. $240 \mathrm{ft}$, ca. $100 \mathrm{ft}$ below the marine limit. Coll. 1960 by R. L. Christie. Comment (J.G.F.) : shells probably originated closely following general deglaciation, at a time when sea penetrated to site from Baffin Bay through lower reaches of Makinson Inlet, a region largely glacier-covered today. Outer and inner fractions of sample were dated separately, after removal of outermost $12 \%$ of shells:

$$
\begin{aligned}
& \text { outer fraction ( } 13-70 \% \text { leach) } 7620 \pm 210 \\
& \text { inner fraction }(71-100 \% \text { leach }) 8200 \pm 220
\end{aligned}
$$

The discrepancy between the two dates is ascribed to contamination of the outer fraction. Each date is based on a single count.

\section{GSC-140. Makinson Inlet ( $\mathrm{N}$ arm), Ellesmere Island $\quad>\mathbf{3 6 , 4 0 0}$}

Peat from upper part of valley wall $5 \mathrm{mi} E$ of head of $\mathrm{N}$ arm of Makinson Inlet, Ellesmere Island, Northwest Territories $\left(77^{\circ} 40^{\prime} \mathrm{N} \mathrm{Lat,} 81^{\circ} 40^{\prime} \mathrm{W}\right.$ Long), from base of 4-ft bed of sandy moss peat exposed in a landslide scar that cuts a meltwater channel. Peat, overlain by boulders in channel bottom and underlain by bouldery gravel on sandstone and shale, probably accumulated on floor of channel. However, the 'old' date reinforces alternative possibility that peat and gravel beneath it comprise remnant of high-terrace deposits 
(interglacial or preglacial) across which channel was eroded. Coll. 1961 by J. G. Fyles.

\section{GSC-118. Augusta Bay, Ellesmere Island}

Marine shells (Mya truncata, Hiatella arctica) from silt underlying $15 \mathrm{ft}$ of sand beneath a beach terrace near S shore of Augusta Bay, Bay Fiord, Ellesmere Island, Northwest Territories ( $78^{\circ} 51^{\prime} \mathrm{N}$ Lat, $81^{\circ} 48^{\prime} \mathrm{W}$ Long). Site, at alt $120 \mathrm{ft}$, is on seaward face of moraine marking a stand of the terminus of former outlet glacier. An associated ice-contact delta at alt $250 \mathrm{ft}$ is believed to mark the sealevel when the glacier margin stood at the moraine. Coll. 1961 by J. G. Fyles. Comment: date is minimum for ice retreat from the moraine, which now lies $10 \mathrm{mi}$ W of the ice cap (see also GSC-170, 175, this list).

\section{GSC-170. Strathcona Fiord (shells), Ellesmere Island $\begin{array}{r}7750 \pm 160 \\ \mathbf{5 8 0 0} \text { B.c. }\end{array}$}

Shells of Mya truncata a few hundred ft $\mathrm{S}$ of Strathcona Fiord opposite mouth of $\mathrm{N}$ arm of Fiord, Ellesmere Island, Northwest Territories $\left(78^{\circ} 42^{\prime} \mathrm{N}\right.$ Lat, $82^{\circ} 51^{\prime} \mathrm{W}$ Long). Sample is from a shell-rich zone including paired valves at the top of massive silt beneath $5 \mathrm{ft}$ of beach gravel at alt $245 \mathrm{ft}$. Site is on seaward face of a valley-side ice-contact deltaic terrace (alt $335 \mathrm{ft}$ ) that probably marks sealevel when the glacier terminus in the fiord stood close to this locality. Coll. 1961 by J. G. Fyles. Comment: date is minimum for glacial retreat from this part of the fiord valley some $20 \mathrm{mi}$ of the present ice cap.

\section{$\begin{array}{lll}\text { GSC-175. Strathcona Fiord (peat), Ellesmere Island } & \mathbf{7 6 8 0} \pm \mathbf{5 7 3 0} \text { B.c. }\end{array}$}

Moss peat from base of sandy peat at depth $9 \mathrm{ft}$ in bottom of a small upland gully, alt $1300 \mathrm{ft}$, at top of valley wall $1 \mathrm{mi} \mathrm{SW}$ of the head of Strathcona Fiord, Ellesmere Island, Northwest Territories $\left(78^{\circ} 33^{\prime} \mathrm{N}\right.$ Lat, 82 $20^{\prime} \mathrm{W}$ Long). Peat is underlain by till and covered by 1 to $2 \mathrm{ft}$ of colluvium. Coll. 1961 by J. G. Fyles. Comment: date is minimum for time since deglaciation of the upland $10 \mathrm{mi}$ W of present ice cap. Compare with dates for early postglacial marine shells from nearby valleys (GSC-118 and 170, this list). Sample held at slightly less than normal pressure during one count; mixed with dead gas during other count.

\section{GSC-129. Borup Fiord, Ellesmere Island $\quad 3720 \pm 140$ 1770 в.c.}

Willow wood and moss from deformed alluvium beneath glacier snout at head of Oobloyah Bay, Borup Fiord, Ellesmere Island, Northwest Territories $\left(80^{\circ} 50^{\prime} \mathrm{N}\right.$ Lat, $83^{\circ} 06^{\prime} \mathrm{W}$ Long $)$, from lower part of $80-\mathrm{ft}$ section of sand, silt, and gravel, covered by 10 to $30 \mathrm{ft}$ of coarse gravel and underlain by marine clay. These deposits, tilted and faulted, now stand at alt 50 to $150 \mathrm{ft}$ at E side of glacier terminus and are exposed by gully of ice-margin stream. They comprise an up-thrust part of the modern outwash plain graded to present sealevel. Coll. 1961 by J. G. Fyles. Comment: glacier has recently encroached on ground that has been ice-free for more than $3700 \mathrm{yr}$ (compare with GSC-105, GSC II, related to a glacier $9 \mathrm{mi} \mathrm{E}$ ). 


\section{Northern Canada, Old Marine Shells}

Marine pelecypod shells on or in surface deposits at various localities within the Arctic Archipelago have yielded 'old' $\mathrm{C}^{14}$ dates. Some of the 'old' samples comprise thick fragments and rare thick whole shells collected above the postglacial marine limit, from sites that lack deposits or landforms suggesting marine inundation: these shells probably were glacially transported from lower positions (see GSC-111, 135, below; GSC-51, GSC I). Other 'old' shell samples come from sites below or approx. at upper limit of marine submergence and, prior to dating, gave no indication of being other than postglacial (GSC-134, 139, 149, and 154, below). Some may be glacial erratics but some may have come directly from unrecognized remnants of interglacial marine deposits or may have been reworked from such deposits by the postglacial sea or by rivers. Stratigraphically distinct interglacial marine deposits so far are known only on N. Axel Heiberg Island and adjacent parts of Ellesmere Island (see GSC-113, below; GSC-65, GSC II).

\section{GSC-111. Hare Cape Ridge, Ellesmere Island $\quad 36,300 \pm 2000$ 34,350 в.с.}

Thick, worn fragments and rare whole shells of Hiatella arctica, Mya truncata, and Astarte sp. from upland extending W from the summit of Hare Cape Ridge, Ellesmere Island, Northwest Territories ( $79^{\circ} 55^{\prime} \mathrm{N}$ Lat, $86^{\circ} 22^{\prime}$ W Long); coll. at alt ca. $2050 \mathrm{ft}$ from several acres of ground surface in an area of sandstone and shale rubble and disintegrated outcrop strewn with erratic stones. Emerged beaches and marine sediments have been recognized only below alt $500 \mathrm{ft}$. The shells at this high locality and at others nearby above $500 \mathrm{ft}$ probably were transported by glacier ice. Outer and inner fractions of sample were dated separately after removal of outermost $10 \%$ of the shells:

$$
\begin{aligned}
& \text { outer fraction ( } 11-50 \% \text { leach) } 30,300 \pm 1600 \\
& \text { inner fraction (51-100\% leach) } 36,300 \pm 2000
\end{aligned}
$$

Coll. 1961 by J. G. Fyles. Comment: sample site is at approx. same locality as L-548 (Lamont VII; Sim, 1961) dated as 19,500 \pm 1100. GSC-51 (28,700 \pm 600 ) is from a similar site at $630 \mathrm{ft} 8 \mathrm{mi} \mathrm{SW}$ (see GSC I). The differences in age between GSC-111 and L-548 as well as between the two fractions of GSC111 are assumed to result from varying degrees of contamination with young C. Thus all the dates are probably minimal.

\section{GSC-134. Swinnerton Peninsula, Ellesmere Island $\quad \mathbf{2 9 , 8 0 0} \pm \mathbf{2 2 0}$}

Shells and fragments of Hiatella arctica, Mya truncata, and rare Astarte from alt 280 to $300 \mathrm{ft}$ on $\mathrm{S}$ side of Swinnerton Peninsula, Ellesmere Island, Northwest Territories ( $77^{\circ} 20^{\prime} \mathrm{N}$ Lat, $81^{\circ} 40^{\prime} \mathrm{W}$ Long); from sandy ground surface approx. at upper limit of emerged marine beaches and at highest occurrence of shells in any quantity (isolated shell fragments were found up to $350 \mathrm{ft}$ ). Coll. 1961 by J. G. Fyles. Comment: shells were expected to be early postglacial (see GSC-146, $8200 \pm 220$, this list, from a nearby site), but apparently belong to an earlier marine episode, probably prior to last glaciation. It is not known whether shells have been redeposited. Dates were determined 
for two preparations:

$\begin{array}{ll}\text { standard preparation }(11-100 \% \text { leach fraction }) & 29,430 \pm 680 \\ \begin{array}{l}\text { inner preparation }(63-100 \% \text { leach fraction, date } \\ \text { based on one } 3 \text {-day count })\end{array} & 29,800 \pm 220\end{array}$

Similarity of the two dates suggests absence of major contamination. Hence, they may indicate the approx. absolute age rather than a minimum (contrast with GSC-111 above).

\section{GSC-113. Rens Fiord, Axel Heiberg Island}

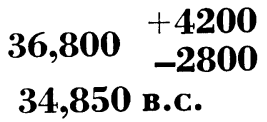

Marine shells (Astarte sp.) from alt 350 to $370 \mathrm{ft}, 3 \mathrm{mi}$ SE of Rens Fiord, $\mathrm{N}$ Axel Heiberg Island, Northwest Territories $\left(81^{\circ} 03^{\prime} \mathrm{N}\right.$ Lat, $93^{\circ} 10^{\prime} \mathrm{W}$ Long). Shells from ground surface on upper part of bank of small river, and derived from stratified silt, sand, and gravel beneath boulder-strewn, apparently glacial deposits. Site is ca. $200 \mathrm{ft}$ above inferred postglacial marine limit. Coll. 1961 by J. G. Fyles. Comment: date agrees with the inference that the deposits are interglacial. The occurrence is similar to GSC-65 (GSC II) coll. $35 \mathrm{mi}$. E on Ellesmere Island. Sample mixed with dead gas for counting; date probably is minimal.

\section{GSC-139. Rens Plain, Axel Heiberg Island}

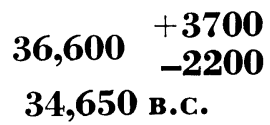

Marine shells (Hiatella arctica) from bank of stream eroded through sandy plain at alt $140 \mathrm{ft}$ on $\mathrm{N}$ Axel Heiberg Island, $5 \mathrm{mi}$ W of Nansen Sound, Northwest Territories $\left(81^{\circ} 05^{\prime} \mathrm{N}\right.$ Lat, $92^{\circ} 25^{\prime} \mathrm{W}$ Long). Sample from $20 \mathrm{ft}$ of sand covered by wash of pebbles and underlain by silt. Coll. 1961 by J. G. Fyles. Comment: site lies below marine limit (ca. 170 to $200 \mathrm{ft}$ ) and shells were expected to date from the postglacial submergence ca. $8000 \mathrm{yr}$ ago. However they must belong to an earlier, possibly interglacial marine interval (see GSC-113, above; GSC-65, GSC II). It is not known whether the inclosing sands were deposited during the same interval or whether they are younger materials containing reworked shells. The freshness and abundance of the shells indicate a nearby primary source. Date is probably minimal.

\section{GSC-149. NW Ellesmere Island}

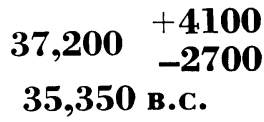

Marine shells (Hiatella arctica) from wall of a gully at alt $150 \mathrm{ft}, 1 \mathrm{mi}$ inland from Nansen Sound $4 \mathrm{mi}$ S of White Point, Ellesmere Island $\left(81^{\circ} 10^{\prime} \mathrm{N}\right.$ Lat, $90^{\circ} 15^{\prime} \mathrm{W}$ Long). Marine limit is at ca. $230 \mathrm{ft}$. Shells are abundant, in silt beneath beach gravel and overlying poorly sorted gravel or till. Coll. 1961 by J. G. Fyles. Comment: for GSC-139, above, applies to this sample.

\section{GSC-154. Nelson Griffiths Point, Melville Island \\ $\mathbf{3 4 , 0 5 0}+\mathbf{- 1 9 5 0}$ 32,100 в.c.}

Marine shell fragments (incl. Hiatella arctica) from surface at Nelson Griffiths Point, Melville Island, Northwest Territories $\left(75^{\circ} 05^{\prime} \mathrm{N}\right.$ Lat, $106^{\circ} 00^{\prime}$ 
W Long), at alt $198 \mathrm{ft}$ on highest emerged beach recognized in the vicinity. Coll. 1962 by W. E. S. Henoch, Geog. Branch, Dept. of Mines and Tech. Surveys, Ottawa. Comment: shells were expected to be early postglacial but evidently belong to an earlier marine episode, probably prior to the last glaciation. It is not known whether shells have been redeposited. Date is probably mininal.

\section{GSC-123. Fury Beach, Somerset Island}

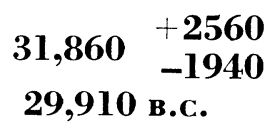

Marine pelecypod shell fragments (Hiatella sp.) from ground surface 12 ni NW of Fury Beach, Somerset Island, Northwest Territories $\left(72^{\circ} 45^{\prime} \mathrm{N}\right.$ Lat, $92^{\circ} 25^{\prime} \mathrm{W}$ Long), in stony marine clay or till at base of end moraine, alt ca. $744 \mathrm{ft}$, ca. $250 \mathrm{ft}$ above marine limit. Coll. 1962 by B. G. Craig. Comment (B.G.C.) : shells antedate last glaciation and were deposited here by glacier ice. Date based on one 3-day count and possibly is minimum.

\section{GSC-135. Port Logan, Boothia Peninsula}

Marine pelecypod shells and fragments (Yoldia arctica, Clinocardium ciliatum, Astarte sp., and Hiatella arctica) from cross-bedded sand $16 \mathrm{mi} \mathrm{W}$ of Port Logan, E side of Boothia Peninsula, Northwest Territories $\left(71^{\circ} 20^{\prime} \mathrm{N}\right.$ Lat, $93^{\circ} 52^{\prime} \mathrm{W}$ Long) ; alt ca. $640 \mathrm{ft}$, possibly ca. $100 \mathrm{ft}$ above marine limit. Coll. 1962 by B. G. Craig. Comment (B.G.C.) : sample was small and mixed with dead gas for counting; date is minimum. Shells antedate last glaciation, and may be indigenous or redeposited.

\section{ARCHAEOLOGIC SAMPLES}

\section{GSC-143. Bennett site, Ontario}

$$
\begin{array}{r}
690 \\
\text { A.D. } 1260
\end{array}
$$

Charcoal from Bennett site, Ontario, in Lot 14, Concession 1, Nelson Tp., Halton Co. ( $43^{\circ} 25^{\prime} \mathrm{N}$ Lat, $79^{\circ} 57^{\prime} \mathrm{W}$ Long), in Pot Concentration 3 under pottery fragments and 4 to 9 in. below the plough zone. Coll. 1962 by J. V. Wright, Nat. Mus. of Canada, Ottawa. Comment (J.V.W.) : site is assigned to the late Pickering branch of the Ontario Iroquois Tradition and was occupied just prior to the Uren site. $\mathrm{C}^{14}$ date is in excellent agreement with the seriational estimate of 1250 A.D.

\section{GSC-162. Morrison's Island, Quebec}

$4700 \pm 150$

2750 в.C.

Charcoal from Morrison's Island 6-site, Pontiac Co., Quebec (45 48.5' $\mathrm{N}$ Lat, $77^{\circ} 02^{\prime} \mathrm{W}$ Long), ca. 3 mi down Ottawa River from Pembroke, Ontario. Sample from squares T14X and T14Y of Burial 17 at alt $426 \mathrm{ft}$; maximum depth of burial 28 in. Coll. 1963 by C. C. Kennedy; subm. by J. V. Wright. Comment (J.V.W.) : date is slightly older than was expected for this site with its Brewerton Focus (Laurentian Archaic) lithic complex and abundance of native copper artifacts.

\section{GSC-148. McCormick Inlet, Melville Island $\quad 1150 \pm 160$}

Charred moss from prehistoric dwelling $6 \mathrm{ft}$ above high tide on shore of 
MicCormick Inlet, Melville Island, Northwest Terirtories $\left(75^{\circ} 49^{\prime} \mathrm{N}\right.$ Lat, $112^{\circ}$ $07^{\prime} \mathrm{W}$ Long). The moss, mixed with fragments of charred wood and bone, occurred on upper surface of a hearthstone and gave impression of having been placed there as fuel. Coll. 1962 by W. E. S. Henoch, Geog. Branch, Ottawa; subm. by W. E. Taylor, Nat. Mus. of Canada. Comment (W.E.T.) : date indicates occupation of site less than $1150 \mathrm{yr}$ ago. Dead moss beneath hearth has date of $1740 \pm 190$, I-840 (Isotopes IV). The few artifacts recovered represent a Dorset Culture occupation and constitute the northwesternmost occurrence of this culture discovered so far. Sample mixed with dead gas for counting; date based on a single 3-day count.

\section{REFERENCES}

Date lists:

GSC I Dyck and Fyles, 1962

GSC II Dyck and Fyles, 1963

Isotopes I Walton, Trautman, and Friend, 1961

Isotopes II Trautman and Walton, 1962

Isotopes IV Trautman, 1964

Lamont VII Olson and Broecker, 1961

Blake, W., Jr., 1963, Notes on glacial geology, northeastern District of Mackenzie: Canada, Geol. Survey Paper 63-28, $12 \mathrm{p}$.

Craig, B. G., in press, Surficial geology of Boothia Peninsula and King William, Somerset, and Prince of Wales Islands, District of Franklin: Canada, Geol. Survey Paper 63-44.

Dyck, Willy, and Fyles, J. G., 1962, Geological Survey of Canada radiocarbon dates I: Radiocarbon, v. 4 , p. 13-26. p. $39-55$.

Lee, $\dot{H}$. A., 1960, Late glacial and postglacial Hudson Bay sea epiosde: Science, v. 131, p. $1609-1611$.

Olson, E. A., and Broecker, W. S., 1961, Lamont natural radiocarbon measurements VII: Radiocarbon, v. 3, p. 141-175.

Prest, V. K., 1962, Geology of Tignish map-area, Prince County, Prince Edward Island: Canada, Geol. Survey Paper 61-28, 15 p. and map.

Sim, V. W., 1961, A note on high-level marine shells on Fosheim Peninsula, Ellesmere Island, N.W.T.: Ottawa, Geog. Branch, Dept. Mines and Tech. Surveys, Geog. Bull. 16 , p. $120-123$.

Trautman, M. A., 1964, Isotopes, Inc. radiocarbon measurements IV: Radiocarbon, v. 6, p. 269-279.

Trautman, M. A., and Walton, Alan, 1962, Isotopes, Inc. radiocarbon measurements II, Radiocarbon, v. 4 , p. $35-42$.

Vernon, Peter, and Hughes, O. L., in press, Surficial geology of Dawson, Larsen Creek, and Nash Creek map-areas, Yukon Territory: Canada, Geol. Survey, Bull.

Walton, Alan, Trautman, M. A., and Friend, J. P., 1961, Isotopes, Inc. radiocarbon measurements I: Radiocarbon, v. 3, p. 47-59.

Willis, E. H., Tauber, H., and Münnich, H. O., 1960, Variations in the atmospheric radiocarbon concentration over the past 1300 years: Am. Jour. Sci. Radioc. Supp., v. 2, p. 1.4 . 